\title{
Forage Yield and Quality in a Great Basin Shrub, Grass, and Legume Pasture Experiment
}

\author{
M.D. RUMBAUGH, D.A. JOHNSON, AND G.A. VAN EPPS
}

\section{Abstract}

A study was conducted in central Utah to determine the forage and protein yield relationships among the components of grassshrub-legume plantings in a semiarid rangeland pasture. Forage and protein yields of crested wheatgrass (Agropyron cristatum) and total herbage increased when fourwing saltbush shrubs (Atriplex canescens) or legumes (A stragalus cicer, $A$. falcatus, or Medicago sativa) were grown in association. The shrub and legume species directly contributed to the increase in these yields and to more rapid regrowth of crested wheatgrass.

Rehabilitation of depleted rangelands in the United States has received much research attention since the mid 1930's. This has guided successful seeding of several million hectares throughout the West. Seeding emphasis was on grasses and only a little attention was given to forbs and almost none to shrubs (Blaisdell 1972). The two crested wheatgrasses, standard crested wheatgrass (Agropyron desertorum) and 'Fairway' crested wheatgrass (Agropyron cristatum), were most commonly seeded.

Fairway crested wheatgrass can grow on dry sites where few other grasses survive (Plummer et al. 1968). It is a preferred species for inclusion in mixtures with other grasses, forbs, and shrubs. Dubbs (1966) found that Fairway crested wheatgrass was more palatable than standard crested wheatgrass over a longer part of the year. Neither sheep nor heifers liked standard crested wheatgrass after heading. Fairway was leafier than standard crested wheatgrass but no higher in protein content.

Fourwing saltbush (Atriplex canescens) is a native, dioecious shrub that occurs on desert and foothill ranges in western America and has been included in some range plantings. It grows to heights of 60 to $180 \mathrm{~cm}$ with most of the seasonal growth in midsummer. This shrub was reported to be one of the most abundant producers of forage and seed tested on Utah game ranges (Plummer et al. 1968). Springfield (1966) considered it to be a useful shrub for ranges of southwestern United States. Palatability of fourwing saltbush forage to sheep was intermediate between prostrate summer cypress (Kochia prostrata) and Artemisia herba alba in Iran where it was considered a promising forage plant for large scale plantings (Nemati 1977). Monsen (1980) successfully interseeded fourwing saltbush and crested wheatgrass into southern Idaho rangelands dominated by sagebrush (Artemisia spp.) and an annual grass. The presence of the saltbush shrubs did not reduce the grass density or herbage yields. Cattle readily accepted the saltbush as a forage species and utilized approximately $50 \%$ of the annual growth.

A number of legume species have been suggested for use in range renovation programs. Townsend et al. (1975) tested 14 legumes and concluded that cicer chickpea milkvetch (Astragalus cicer), sicklepod milkvetch (Astragalus falcatus), and alfalfa (Medicago sativa) merited additional evaluation for potential use under dryland or range conditions. Cicer milkvetch was considered adapted

Authors are research geneticist and plant physiologist, USDA, ARS, Crops Research Laboratory, UMC 63, Utah State University, Logan, 84322, and associate professor, Range Science Department, Utah State University, Logan 84322.

Contribution from the USDA-ARS and the Utah Agricultural Experiment Station,

Logan, Utah. lournal Paper No. 2685

Manuscript received April 25, 1981. to areas of the Central Great Plains that receive $40 \mathrm{~cm}$ or more precipitation annually. Cornelius and Talbot (1955) recommended the use of cicer milkvetch at elevations from 1,650 to $2,300 \mathrm{~m}$ in northeastern California. Hafenrichter et al. (1968) stated that it was adapted in parts of the Pacific Northwest and Great Basin states above $1,200 \mathrm{~m}$ where it was superior to alfalfa in longevity of stand and yield. Cicer milkvetch grew well within the more favorable part of the pinyon-juniper and big sagebrush belts at lower elevations in Utah (Plummer et al. 1968). It was described as a useful rhizomatous legume which was productive in association with shrubs and which was tolerant of partial shading.

Sicklepod milkvetch has a long, heavy taproot that can penetrate more than $2 \mathrm{~m}$. Plummer et al. (1968) reported that the plant was best adapted to the mountain brush zone in Utah but grew well in the more favorable areas of pinyon-juniper and big sagebrush types. This species was grazed by big game in summer but mature plants were valuable in the winter because they often protruded above the snow. Williams et al. (1976) found sicklepod milkvetch to be high in toxic nitrogenous compounds. They suggested that existing stands should be eradicated. Cicer milkvetch does not present toxicity hazards for grazing ruminants.

Alfalfa has been used successfully to improve yields of crested wheatgrass. Lorenz and Rogler (1962) were able to establish a few alfalfa plants in an old crested wheatgrass pasture at Mandan, N. Dak., with an average annual precipitation of $40 \mathrm{~cm}$ and an average annual evaporation rate from a free water surface of $83 \mathrm{~cm}$. Plots where these alfalfa plants were growing yielded as much forage as crested wheatgrass plots treated with $34 \mathrm{~kg} \mathrm{~N} / \mathrm{ha}(30 \mathrm{lb}$ $\mathrm{N} / \mathrm{acre}$ ) in the fall of each year. Wheatgrass grown in a mixture with alfalfa was slightly higher in protein content than grass grown without alfalfa (Rogler and Lorenz 1969). Throughout the growing season, the protein content of the alfalfa component was twice as high as that of grass grown without alfalfa. Alfalfa is adapted to drier sites than the milkvetches and certain cultivars such as 'Rambler' have been described by Plummer et al. (1968) as being suited to ranges where annual precipitation exceeds $23 \mathrm{~cm}$.

The objective of this research was to measure and interpret the interactions of shrub, grass, and legume components on forage yield and quality in 3 selected species mixtures that have a potential value for range improvement in the Intermountain Area.

\section{Methods}

The experimental site was located on the Nephi Field Station $120 \mathrm{~km}$ south of Salt Lake City, Utah. This station is on an alluvial fan known as the Levan Ridge and is at an elevation of $1,615 \mathrm{~m}$. The soil is a Nephi silt loam derived from the weathering of adjacent mountain ranges, reddish brown in color, and uniformly 3 $m$ or more in depth. It has a nitrogen content of $0.1 \%$ in the surface foot (Bennett et al. 1954). Long-term (1903-1979) weather records at the station show that the average annual precipitation is $32 \mathrm{~cm}$ with approximately one-third occurring during the spring months of March through May. The frost-free period at the site is 110 days. Average July daily temperature is $24^{\circ} \mathrm{C}$ and daily maximum temperature in July commonly exceeds $38^{\circ} \mathrm{C}$. Eva poration from a free water surface for the 7 months April to October over the 
period 1908 to 1941 averaged $121 \mathrm{~cm}$ or approximately 3.78 times the total precipitation for the year.

This experiment was initiated on November 24,1970 by seeding Fairway crested wheatgrass on the entire site with rows oriented north to south and spaced $53 \mathrm{~cm}$ (21 inches) apart. The shrub and legume components of the planting were established April 9, 1971 with the rows in an east-west direction. Single rows of fourwing saltbush were transplanted from bare root stock continuously across the site at $6-\mathrm{m}$ ( 20 foot) intervals and extending a distance of $73 \mathrm{~m}$ (240 feet). A double row of legumes $61 \mathrm{~cm}$ ( 2 feet) apart was seeded parallel to the shrub rows and $122 \mathrm{~cm}$ ( 4 feet) from it. Each legume plot was $9 \mathrm{~m}$ (30 feet) long. The 5 legume treatments were: (1) no legume, (2) Rambler alfalfa, (3) cicer milkvetch, (4) sicklepod milkvetch, and (5) a mixture of the 3 legume species. The experimental design was a randomized complete block with 3 replications. A single replicate is diagrammed in Figure 1-A.

Forage yields were measured at 4 times: August 28-30, 1978; May 21-25, 1979; July 9-12, 1979; and August 27-30, 1979. At each harvest a $107-\mathrm{cm}(42 \mathrm{inch})$ wide belt transect $6 \mathrm{~m}$ ( 20 feet) long, consisting of twenty 30-cm (1 foot) segments, was established on each plot at right angles to and centered on the row of shrubs. This is illustrated in Figure 1-B. Transect locations were selected to ensure that the 3 kinds of species, grass, shrub, and legume, would be included in each plot. Only forage produced during the current season was harvested and each species was harvested separately within each segment of the transect. At the last harvest in 1979, those transects previously clipped were reharvested. All forage was dried in a forced air oven at $38^{\circ} \mathrm{C}$. Crude protein yields were calculated by multiplying the oven dry forage weights by their nitrogen concentration determined from chemical analyses (Chatterton and Silvius 1979) and by the multiplication constant 6.25 . Soil moisture was determined at each harvest for each species association and replication by gravimetric procedures. Soil depths sampled were $0-15,15-30,30-61$, and $61-91 \mathrm{~cm}$.

Species mixtures were defined by the species growing within each transect segment. The 9 mixtures are listed below:

Crested wheatgrass grown alone.

Crested wheatgrass grown with fourwing saltbush.

Crested wheatgrass grown with alfalfa.

Crested wheatgrass grown with cicer milkvetch.

Crested wheatgrass grown with sicklepod milkvetch.

Fourwing saltbush grown with crested wheatgrass.

Grass - Legume- Shrub Plot Layout

Field Station at Nephl, Utoh

A

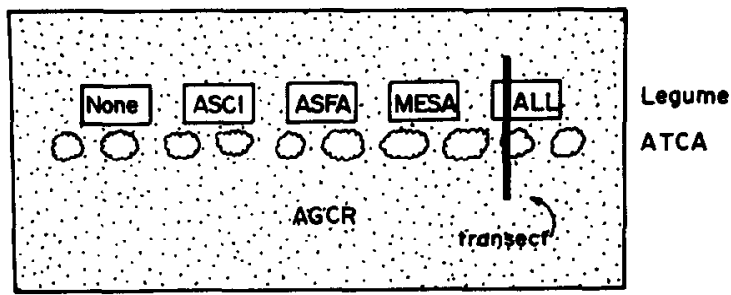

B

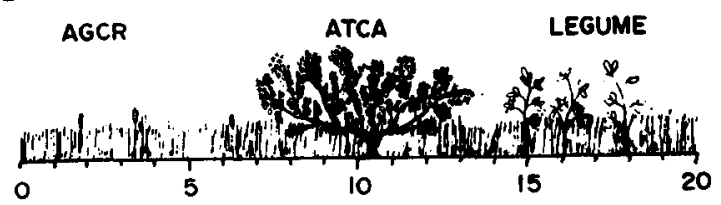

Fig. 1A. Diagram of one replication in the experimental planting. None $=$ no legumes, $A S C I=$ Astragalus cicer, $A S F A=$ Astragalus falcat us, $M E S A=$ Medicago sativa, $A L L=$ a mixture of the 3 legumes, $A T C A=$ Atriplex canescens, and $A G C R=$ Agropyron cristatum. 1B. Illustration of plant growth in the 20 increments of a typical transect.
Alfalfa grown with crested wheatgrass.

Cicer milkvetch grown with crested wheatgrass.

Sicklepod milkvetch grown with crested wheatgrass.

\section{Results}

\section{Precipitation and Soil Moisture}

Precipitation at the Nephi Field Station in 1978 deviated markedly from the long-term average with more than normal accumulative amounts of moisture recorded for each of the 12 months (Fig. 2). Weather in 1979 followed the average precipitation pattern much closer than in 1978. Moisture accumulation for 1979 was above normal from January through May but somewhat below average the remainder of the year. The summers of both years were periods of plant drought stress. Precipitation during June and July 1978 totaled $0.03 \mathrm{~cm}$ and only slightly more, $0.74 \mathrm{~cm}$, was measured in these 2 months in 1979 .

Soil moisture at harvest averaged $9.4 \%$ during the course of the experiment. Analysis of variance revealed significant differences $(P<0.01)$ among dates and depths of sampling but not among species mixtures. None of the interactions among the time, depth, and species mixture factors were statistically significant $(P>0.05)$. Soil moisture was $5.2 \%$ on August 30,1978 . This was less than at any of the other harvest dates. Percentages were 12.8, 10.1, and 9.6 in May, July, and August 1979, respectively. Soil samples nearest the surface tended to be drier than those at greater depths in the profile on all dates. Moisture in the $0-15 \mathrm{~cm}$ zone averaged $7.4 \%$, $10.8 \%$ in the $15-30 \mathrm{~cm}$ zone, $9.5 \%$ in the $30-61 \mathrm{~cm}$ zone, and $9.9 \%$ in the $61-91 \mathrm{~cm}$ zone. Although the effects of species mixture were not statistically significant, it is of interest to note that the soil was driest, $8.5 \%$ moisture, under cicer milkvetch plants and wettest, $10.2 \%$ moisture, under sicklepod milkvetch.

The differences in precipitation caused large changes in the variables measured during the experiment. Mean forage dry matter harvested in August 1978 was $296 \mathrm{~g} / \mathrm{m}^{2}$ and in August 1979 was $\mathrm{g} / \mathrm{m}^{2}$ (Table 1). Approximately half of the dry matter harvested in 1978 was from fourwing saltbush while in 1979 the shrub component was less than a third of the current growth (Fig. 3). Increased soil moisture during the first part of 1978 apparently permitted more plant growth than in 1979. The greater biomass in turn resulted in drier soils in August 1978 than in August 1979. Protein content differed from $8.0 \%$ in the first year to $5.9 \%$ in the second. Protein yield, averaged over all treatments, was $24 \mathrm{~g} / \mathrm{m}^{2}$ in August 1978 and only $9 \mathrm{~g} / \mathrm{m}^{2}$ in August 1979. The differences between the means for each of the three variables for these 2 harvests were highly significant $(P<0.01)$. However, the interaction of years by treatments for each of the 3 plant response variables was not significant $(P>0.05)$. Since the 1979 data were obtained in a more

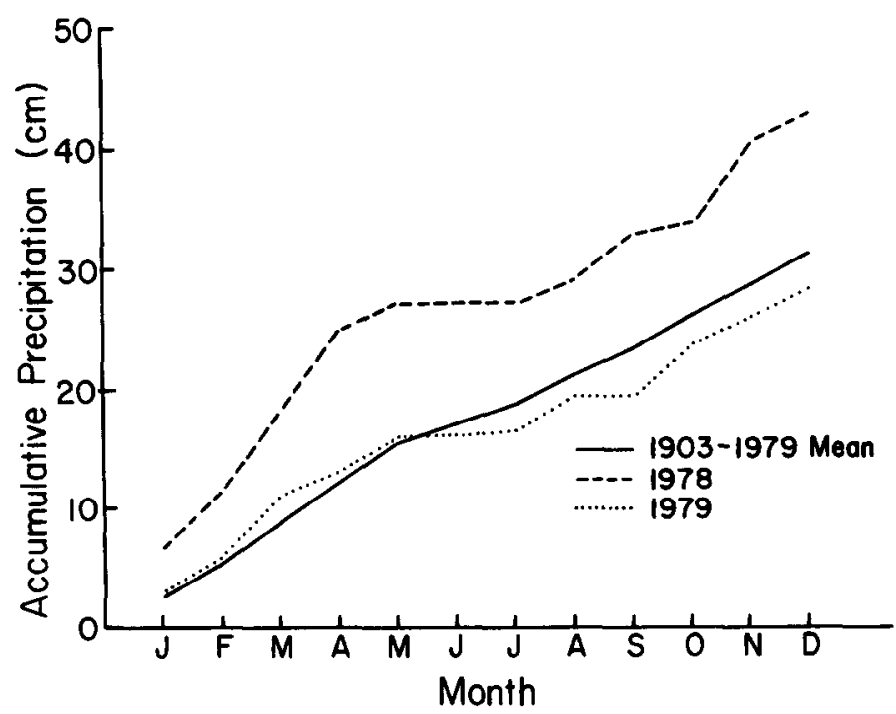

Fig. 2. Accumulative annual precipitation at Nephi, Utah. 
Table 1. Mean forage and protein yields and protein concentrations of 5 seeding treatments on 4 harvest dates in 1978 and 1979 at Nephi, Utah. Standard errors are shown in parentheses.

\begin{tabular}{|c|c|c|c|c|}
\hline \multirow{2}{*}{$\begin{array}{l}\text { Seeding } \\
\text { treatment }\end{array}$} & \multicolumn{4}{|c|}{ Harvest date } \\
\hline & August 1978 & May 1979 & July 1979 & August 1979 \\
\hline & \multicolumn{4}{|c|}{ Forage yield $\left(\mathrm{g} / \mathrm{m}^{2}\right)$} \\
\hline (1) Check & $286(38)$ & $99(10)$ & $166(21)$ & $131(17)$ \\
\hline (2) M. sativa & $310(35)$ & $155(15)$ & $184(18)$ & $211(23)$ \\
\hline (3) A. cicer & $261(33)$ & $108(10)$ & $190(15)$ & $163(21)$ \\
\hline (4) A. falcatus & $349(47)$ & $146(10)$ & $230(20)$ & $157(16)$ \\
\hline (5) Mixture & $273(33)$ & 117 (9) & $198(20)$ & $135(14)$ \\
\hline Mean & $296(17)$ & $125(5)$ & $194(8)$ & $159(8)$ \\
\hline \multicolumn{5}{|l|}{ L.S.D. } \\
\hline$(0.05)$ & 15 & 5 & 8 & 8 \\
\hline$(0.01)$ & 21 & 6 & 10 & 10 \\
\hline & \multicolumn{4}{|c|}{ Protein concentration $(\%)$} \\
\hline (1) Check & $8.4(0.5)$ & $14.9(0.4)$ & $7.1(0.3)$ & $6.0(0.3)$ \\
\hline (2) $M$. sativa & $7.5(0.4)$ & $15.2(0.3)$ & $7.0(0.3)$ & $5.6(0.3)$ \\
\hline (3) A. cicer & $7.7(0.4)$ & $14.6(0.2)$ & $5.9(0.2)$ & $6.0(0.3)$ \\
\hline (4) A. falcatus & $8.6(0.4)$ & $14.5(0.5)$ & $6.6(0.3)$ & $5.9(0.3)$ \\
\hline \multirow[t]{6}{*}{ (5) Mixture } & $7.4(0.4)$ & $15.1(0.3)$ & $7.4(0.3)$ & $5.1(0.3)$ \\
\hline & $8.0(0.2)$ & $15.0(0.2)$ & $6.9(0.1)$ & $5.9(0.1)$ \\
\hline & & & & \\
\hline & 0.5 & 0.4 & 0.4 & 0.4 \\
\hline & 0.7 & 0.5 & 0.5 & 0.5 \\
\hline & \multicolumn{4}{|c|}{ Protein yield $\left(\mathrm{g} / \mathrm{m}^{2}\right)$} \\
\hline (1) Check & $24(4)$ & $15(2)$ & $12(2)$ & $8(1)$ \\
\hline (2) $M$. sativa & $23(4)$ & $24(3)$ & $13(1)$ & $12(2)$ \\
\hline (3) A. cicer & $20(4)$ & $16(1)$ & $11(1)$ & $10(2)$ \\
\hline (4) A. falcatus & $30(4)$ & $21(2)$ & $15(1)$ & 9 (1) \\
\hline (5) Mixture & $20(4)$ & $18(1)$ & $15(2)$ & $7(1)$ \\
\hline Mean & $24(2)$ & 19 (1) & $13(0)$ & $9(0)$ \\
\hline$(0.05)$ & 2 & 1 & 1 & 1 \\
\hline$(0.01)$ & 3 & 2 & 1 & 2 \\
\hline
\end{tabular}

'Check $=$ crested wheatgrass and fourwing saltbush without a legume component. Treatments $2-5$ contained crested wheatgrass, fourwing saltbush, and the indicated legume.

typical moisture environment for the experimental site than the 1978 data and the interaction with treatments was nonsignificant, the following interpretations often will he based primarily on the 1979 results.

\section{Forage Yields}

Mean forage yield in the experiment during 1979 was $159 \mathrm{~g} / \mathrm{m}^{2}$. Fairway crested wheatgrass produced $110 \mathrm{~g} / \mathrm{m}^{2}$ or $68.8 \%$ of the total. Saltbush yielded $30 \mathrm{~g} / \mathrm{m}^{2}$ or $18.4 \%$ and the legumes averaged

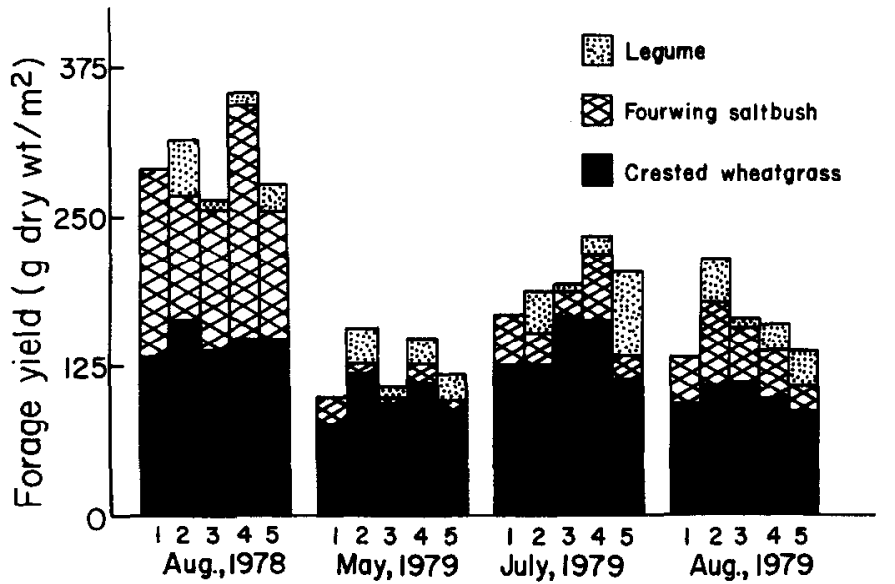

Time and Treatment

Fig. 3. Forage yields on 4 sampling dates of the crested wheatgrass, fourwing saltbush, and legume components in 5 seeding treatments. Each bar represents means of 60 measurements.
$20 \mathrm{~g} / \mathrm{m}^{2}$ or $12.8 \%$ of all dry forage. Forage yield increased from May to July but then declined (Fig. 3). At no time in 1979 was it equal to the amounts measured for any treatment in August 1978. The quantity of shrub foliage relative to that of the grass and legumes tended to increase as the growing season progressed, $9.8 \%$ of all forage in May, $16.9 \%$ in July, and $27.0 \%$ in August. Treatment 2 which included alfalfa as the legume component yielded more on the average than the other treatments but not significantly more than treatment 4 with sicklepod milkvetch.

Orthogonal single degree of freedom partitioning of the treatment variance of 1979 data demonstrated that the mean total forage weight of transects containing cicer milkvetch was not different than that of transects of sicklepod milkvetch $(P>0.05)$. In the same way, the average forage yield of treatments 2 and 5 , each of which contained alfalfa, did not differ from that of treatments 3 and 4 , which contained the two milkvetch species. However, the check treatment did yield significantly less than the average of the 4 legume treatments $(P<0.01)$.

It was anticipated that crestcd wheatgrass would yield more than the shrub or legume components since grass was seeded in all segments of each transect and the shrub and legumes were restricted to only a part of each transect in which they occurred. Crested wheatgrass tended to produce more forage in transects containing a legume than in those in which there was no legume (Fig. 3). In 1979 the mean weight of grass in treatments 2 through 5 was $113 \mathrm{~g} / \mathrm{m}^{2}$ in contrast to $98 \mathrm{~g} / \mathrm{m}^{2}$ in treatment 1 which did not contain a legume. Treatment 5 in which the 3 legumes were seeded as a mixture contained slightly less grass forage than the check treatment although the difference was not statistically significant $(P>0.05)$.

Crested wheatgrass responded dra matically to close association with the saltbush and the legumes (Fig. 4). The weight of forage per harvest in 1979 was plotted for each of the 20 transect segments averaged over all treatments, harvests, and replications. Segments 1-5 only occasionally contained either saltbush or legume foliage. Segments 6-13 included considerable saltbush vegetation and a marked increase in the quantity of wheatgrass was detected. An average of $138 \mathrm{~g} / \mathrm{m}^{2}$ of crested wheatgrass forage was clipped in segments 6 through 13 in contrast to an average of $68 \mathrm{~g} / \mathrm{m}^{2}$ in segments 1 through 5 where there was little impact of either saltbush or the legume species. Most of the legume top growth was located in segments 14 through 17. Crested wheatgrass grown in that section of the transects yielded an average of $124 \mathrm{~g} / \mathrm{m}^{2}$ or about $10 \%$ less than similar segments containing more shrubs but $183 \%$ of those segments without either saltbush or legumes. At the south end of the transects where minimal legume or saltbush foliage was harvested, segments $18-20$ averaged $84 \mathrm{~g} / \mathrm{m}^{2}$ crested

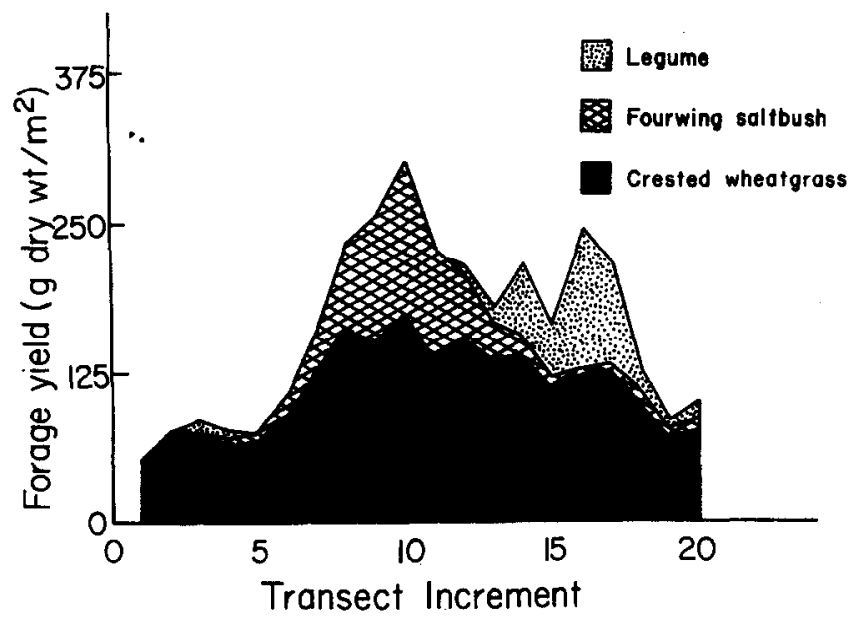

Fig. 4. Forage yields of crested wheatgrass, fourwing saltbush, and legumes in the 20 transect increments during 1979 when averaged over all legume treatments and harvest dates. 
wheatgrass. This was slightly more than the amount at the north end of the transects.

Single degree of freedom contrasts for the crested wheatgrass yields of the 5 treatments indicated that there was no difference between the effect of cicer milkvetch and that of sicklepod milkvetch $(P>0.05)$. Treatments which included alfalfa ( 2 and 5$)$ were superior to those including only milkvetch species ( 3 and 4 ) as the legume component $(P<0.01)$ and the average of the legume treatments was better than the check treatment (1) containing only the grass and shrub species $(P<0.05)$.

Seasonal distribution of forage yield varied somewhat among the 5 plant species. Fourwing saltbush contributed to the total forage yields throughout the 1979 growing season. Average yields $\left(\mathrm{g} / \mathrm{m}^{2}\right)$ were 12 in May, 33 in July, and 43 in August. Despite considerable leaf drop induced by dessication, alfalfa also maintained its dry matter yield throughout the summer. Alfalfa yields in treatment 2 at the May, July, and August harvests were 29, 36, and $37 \mathrm{~g} / \mathrm{m}^{2}$, respectively. Crested wheatgrass and the 2 vetch species tended to deteriorate as the season progressed. Fairway crested wheatgrass produced an average of $96 \mathrm{~g} / \mathrm{m}^{2}$ topgrowth by the May harvest, $136 \mathrm{~g} / \mathrm{m}^{2}$ by July, and $97 \mathrm{~g} / \mathrm{m}^{2}$ by August. Corresponding values for cicer milkvetch in treatment 3 were 10,6 , and $7 \mathrm{~g} / \mathrm{m}^{2}$ and for the sicklepod milkvetch in treatment 4 were 21,17 , and $20 \mathrm{~g} / \mathrm{m}^{2}$. The deterioration of the grass component was reflected by the drop in mean total forage yield from $194 \mathrm{~g} / \mathrm{m}^{2}$ in July to $159 \mathrm{~g} / \mathrm{m}^{2}$ in August (Table 1).

Maximum mean weights of the legumes occurred in segments 16 or 17 of the transects in which they were seeded. Alfalfa averaged $238 \mathrm{~g} / \mathrm{m}^{2}$ dry forage in segment 16 of treatment 2 transects. Maximums for cicer milkvetch and sicklepod milkvetch were 65 and 112 $\mathrm{g} / \mathrm{m}^{2}$ or less than half the amount provided by alfalfa. Fourwing saltbush vegetation was centered on segment 10 and amounted to $126 \mathrm{~g} / \mathrm{m}^{2}$ when averaged over all treatments and harvests. Maximum yield of crested wheatgrass also was located in increment 10 and was $172 \mathrm{~g} / \mathrm{m}^{2}$.

The impact of the shrub and legume species upon forage yield of Fairway crested wheatgrass in this experiment was significant and positive. The simple correlation between the forage weights of the shrub and grass species in the transect increments of the three harvests was positive $(r=0.28)$ and significant $(R<0.01)$. These two species were compatible and grew well in association with each other. The response to alfalfa was similar to that observed in the Northern Great Plains by Lorenz and Rogler (1962). At Nephi, Utah, the two species of milkvetch did not produce as much forage as alfalfa and did not induce as much growth response by crested wheatgrass as did alfalfa. Cicer milkvetch and sicklepod milkvetch apparently are not as well adapted to the environment of the study site as to the locations considered by Hafenrichter et al. (1968), Plummer et al. (1968), and Townsend et al. (1975).

The favorable interaction of the fourwing saltbush and crested wheatgrass supported the conclusion of Monsen (1980) that the presence of saltbush shrubs did not reduce grass density or herbage yields. We found more than twice as much grass forage in segments of the transects containing the shrub as in segments where only rass was planted. This could be a response to nitrogen and mineral accumulation under the shrub.

Fairchild and Brotherson (1980) found greater concentrations of minerals under fourwing saltbush than under 5 other shrub species. Garcia-Moya and McKell (1970), Charley and West (1975), Charley (1977), and Fairchild and Brotherson (1980) measured nitrogen accumulation under shrubs and detected an associated concentration decline in the surrounding environment. An increase in nit rogen fixation by free living microorganisms in and under litter mats, animal activity, and canopy capture of wind transported soils were suggested as possible causes of the nitrogen gradients.

It is difficult to accept the increased growth of crested wheatgrass measured in this experiment as a general response to the presence of shrubby plants since Rittenhouse and Sneva (1976) found a negative correlation between Wyoming big sagebrush (Artemisia tridentata Wyomingensis) crown cover and crested wheatgrass cover. Frischknecht (1963) also measured a decrease in crested wheatgrass yield under crowns of big sagebrush but an increase under crowns of rubber rabbitbrush (Chrysothamnus nauseosus). He attributed these responses to differences in the location of roots of the shrubs. Big sagebrush had highly developed lateral roots extending into the same zone as those of the grass, whereas relatively few lateral roots of rubber rabbit brush occurred in that zone. Also, the most active growth periods of crested wheatgrass and big sagebrush coincided, but crested wheatgrass made most of its growth prior to the most active growth of rubber rabbitbrush. Both brush species increased the deposition of drifting snow and the soil moisture around the plants in early spring. In our study, differential snow catchment by the shrubs and legumes did not appear to explain the grass response since significant differences in soil moisture among the species mixtures were not detected. Whatever the mechanism, Fairway crested wheatgrass was very responsive to the presence of fourwing saltbush and the legume species used in this experiment.

\section{Protein Content and Yield}

Average crude protein concentrations of all forage was highly dependent upon date of harvest. It ranged from a high of $15.0 \%$ in May to a low of $5.9 \%$ in August, 1979 (Table 1). These large differences attributable to time were statistically significant $(P<0.05)$ whereas the small differences among treatments were not $(P>0.05)$. This also was true of the mean percent protein of crested wheatgrass and of the square root transformations of the wheatgrass and total forage protein percentages.

The plant species included in the 5 seeding treatments varied in their protein content at each harvest (Table 2). Foliage of the shrub and legumes contained approximately twice the protein concentration of the grass foliage on every one of the 4 sampling dates. The percent protein of crested wheatgrass tended to increase when that species was grown in proximity to saltbush or the legumes. Transect segments with only grass grew forage with $5.5 \%$ protein when averaged for the 4 harvests. When the grass grew in segments where fourwing saltbush leaves were harvested, the grass tissue contained $5.8 \%$ protein. Similar percentages when it was grown with the

Table 2. Mean protein concentration (\%) in forage of individual species harvested on 4 dates in 1978 and 1979 at Nephi, Utah. Standard errors are shown in parentheses.

\begin{tabular}{|c|c|c|c|c|c|}
\hline $\begin{array}{l}\text { Species } \\
\text { analyzed }\end{array}$ & $\begin{array}{l}\text { Associated } \\
\text { species }\end{array}$ & August 1978 & May 1979 & $\begin{array}{l}\text { est date } \\
\text { July } 1979\end{array}$ & August 1979 \\
\hline $\begin{array}{l}\text { A. cristatum } \\
\text { A. cristatum } \\
\text { A. cristatum } \\
\text { A. cristatum } \\
\text { A. cristatum } \\
\text { A. canescens } \\
\text { M. sativa } \\
\text { A. cicer } \\
\text { A. falcatus }\end{array}$ & $\begin{array}{l}\text { A. canescens } \\
\text { M. sativa } \\
\text { A. cicer } \\
\text { A. falcatus } \\
\text { A. cristatum } \\
\text { A. cristatum } \\
\text { A. cristatum } \\
\text { A. cristatum } \\
\text { ) }\end{array}$ & $\begin{array}{r}3.1(0.1) \\
3.8(0.3) \\
3.7(0.1) \\
3.8(0.4) \\
3.8(0.3) \\
12.6(0.5) \\
7.7(0.7) \\
8.6(0.0) \\
8.0(0.2) \\
0.3 \\
0.4\end{array}$ & $\begin{array}{l}10.9(1.2) \\
11.4(0.9) \\
12.4(1.3) \\
11.2(1.0) \\
11.9(1.1) \\
28.0(3.1) \\
21.2(1.2) \\
21.8(1.4) \\
25.8(2.6) \\
1.3 \\
1.8\end{array}$ & $\begin{array}{r}4.7(0.2) \\
4.8(0.6) \\
4.9(0.5) \\
5.0(0.2) \\
5.1(0.3) \\
13.6(1.4) \\
9.7(0.6) \\
12.3(1.1) \\
14.8(0.8) \\
0.6 \\
0.8\end{array}$ & $\begin{array}{l}3.3(0.2) \\
3.2(0.1) \\
4.0(0.3) \\
3.4(0.2) \\
4.0(0.4) \\
12.5(0.7) \\
5.2(0.6) \\
5.8(0.2) \\
5.2(0.4) \\
0.3 \\
0.4\end{array}$ \\
\hline
\end{tabular}


legumes were $6.2 \%$ for alfalfa, $5.8 \%$ for cicer milkvetch, and $6.2 \%$ for sicklepod milkvetch. The increase in protein was greatest at the May harvest and least at the July harvest.

Greatest protein yield was obtained in August 1978 (Table 1). In 1979 maximum protein was found in the forage clipped in May. The values for the two August dates were significantly different $(P<0.01)$. In 1978 there was $24 \mathrm{~g} / \mathrm{m}^{2}$ protein compared to $9 \mathrm{~g} / \mathrm{m}^{2}$ in August 1979 . This was caused prima rily by the difference in growth of the fourwing saltbush in the 2 years (Fig. 5). Protein yield of saltbush in 1978 was more than twice the amount of that in the last harvest of 1979. This resulted from a change in forage quantity rather than in protein concentration. Protein yield from the grass in 1978 was $148 \%$ of that in August 1979.

Some differences among the seeding treatments for mean total protein yield in 1979 were detected. Treatment 2 with alfalfa and treatment 4 with sicklepod milkvetch were superior to treatment 3 with cicer milkvetch and treatment 1 with no legumes $(P<0.01)$. Treatment 5 containing the legume mixture was intermediate in total protein production. Protein yield of crested wheatgrass was significantly higher in transects with legumes than in those without legumes $(P<0.05)$.

Mean total protein yield for each segment of the transects in 1979 was plotted (Fig. 6). The impact of the shrub and legume species and of the response by crested wheatgrass to an association with these other species were readily apparent. Major peaks were located at segment 10 where saltbush was centered and at segment 16 where the legumes were centered. Crested wheatgrass protein yield was lowest in segments 1 through 5 where it was the only species present. Step-wise multiple regression analysis of total protein yield per transect segment in 1979 indicated that the most important predictive variable was forage weight of saltbush. Other va riables in decreasing order of predictive value were forage weight of alfalfa, protein content of crested wheatgrass, forage weight of crested wheatgrass, forage weight of sicklepod milkvetch, forage weight of cicer milkvetch, protein content of sicklepod milkvetch, forage weight of cicer milkvetch, protein content of saltbush, and protein content of alfalfa. The multiple correlation coefficient was $R=0.91$. Eighteen percent of the variation observed in total protein yield of the segments was not explained by the variation found in the component parts used to compute total protein yield.

No significant differences were detected for any of the recognized sources of variation for nitrogen content of soil samples taken from the 4 depths under each of the 5 plant species in August 1979. The mean of all samples was $0.11 \%$ nitrogen. Nitrogen concentration did tend to decline with increasing depth at which the samples were obtained. Values were $0.15 \%, 0.11 \%, 0.11 \%$, and $0.08 \%$ for the $0-15,15-30,30-61$, and $61-91 \mathrm{~cm}$ zones, respectively.

These results document the value of including fourwing saltbush and legumes in plantings of crested wheatgrass. Increased protein

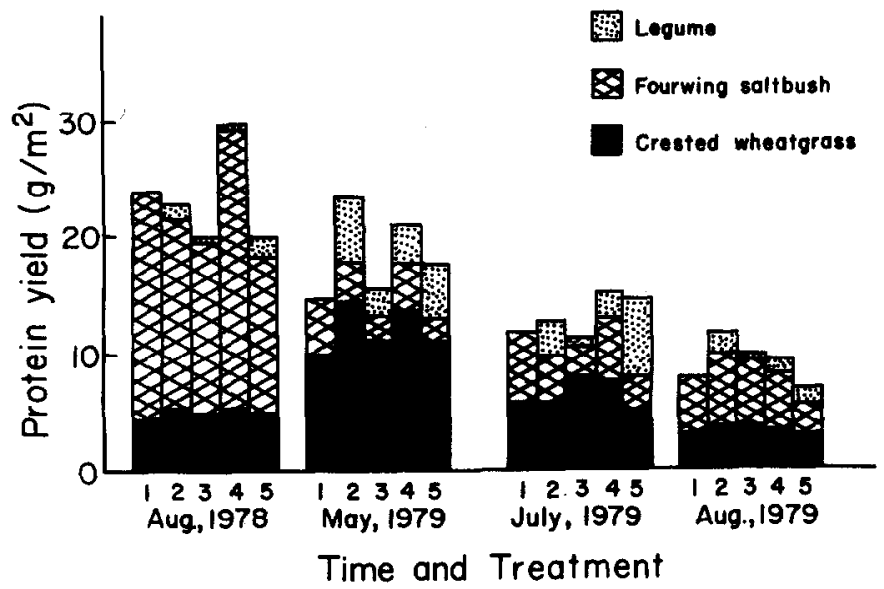

Fig. 5. Protein yields on 4 sampling dates of the crested wheatgrass, fourwing saltbush, and legume components in 5 seeding treatments. Each bar represents means of 60 measurements.

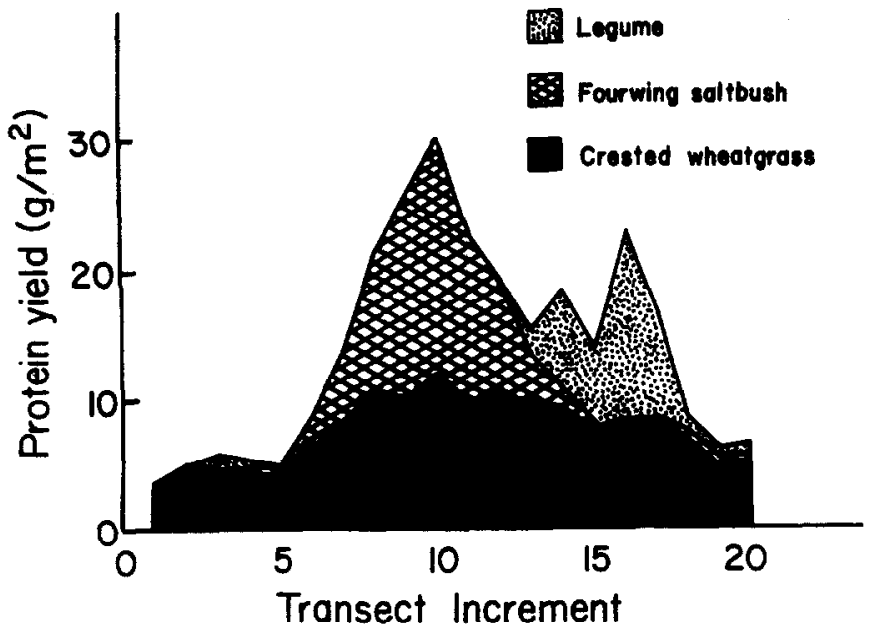

Fig. 6. Protein yields of crested wheatgrass, fourwing saltbush, and legumes in the 20 transect increments during 1979 when averaged over all treatments and harvest dates.

concentration, forage yield, and protein yield of crested wheatgrass and of the total herbage resulted.

\section{Regrowth}

All transects were reharvested in August 1979. The time of the previous clipping had a significant $(\boldsymbol{P}<0.01)$ effect on the quantity of forage regrowth. Average yields from all species and treatments were 168,49 , and $5 \mathrm{~g} / \mathrm{m}^{2}$ from transects first harvested in August 1978, May 1979, and July 1979, respectively. Differences among seeding treatments were not statistically significant $(P>0.05)$ but the interaction of time of first harvest with seeding treatments was significant $(P<0.05)$. The check treatment and treatment 3 with cicer milkvetch had somewhat less regrowth than the other 3 treatments in transects first harvested in August 1978 but more regrowth than the other 3 treatments in transects first harvested in July 1979.

The rates of regrowth of species included in pasture improvement plantings and the effect that each has on other species with which they are grown is important in planning management strategies. Crested wheatgrass grown by itself at Nephi and first harvested in August 1978 yielded $63 \mathrm{~g} / \mathrm{m}^{2}$ when reharvested a year later (Table 3). When it was first harvested in May or July 1979, recovery was very low. Fourwing saltbush, however, yielded as much regrowth when first clipped in May $1979,145 \mathrm{~g} / \mathrm{m}^{2}$, as when first clipped in August $1978,131 \mathrm{~g} / \mathrm{m}^{2}$. It could, therefore, be grazed in either fall or spring and be expected to recover equally well for grazing the following August. This was not true of crested wheatgrass.

Inclusion of legumes in the planting had a synergistic effect on the recovery of crested wheatgrass from the August 1978 clipping. Grass yields from transect increments containing alfalfa, cicer

Table 3. Regrowth yields $\left(\mathrm{g} / \mathrm{m}^{2}\right)$ of individual species in August 1979 after prior clipping treatments. Standard errors are shown in parentheses.

\begin{tabular}{llccc}
\hline \multirow{2}{*}{$\begin{array}{l}\text { Species } \\
\text { harvested }\end{array}$} & $\begin{array}{l}\text { Associated } \\
\text { species }\end{array}$ & \multicolumn{3}{c}{ Time of first harvest } \\
\cline { 3 - 5 } & & August 1978 & May 1979 & July 1979 \\
\hline A. cristatum & - & $63(5)$ & $3(1)$ & $3(2)$ \\
A. cristatum & A. canescens & $157(10)$ & $2(1)$ & $1(1)$ \\
A. cristatum & M. sativa & $139(26)$ & $0(0)$ & $0(0)$ \\
A. cristatum & A. cicer & $105(24)$ & $1(0)$ & $8(2)$ \\
A. cristatum & A. falcatus & $85(17)$ & $0(0)$ & $0(0)$ \\
A. canescens & A. cristatum & $131(21)$ & $145(19)$ & $8(3)$ \\
$M$. sativa & A. cristatum & $112(30)$ & $45(12)$ & $0(0)$ \\
A. cicer & A. cristatum & $14(5)$ & $4(2)$ & $0(0)$ \\
A. falcatus & A. cristatum & $47(24)$ & $3(2)$ & $0(0)$ \\
L.S.D. (0.05) & & 18 & 11 & 3 \\
\multicolumn{1}{c}{$(0.01)$} & & 24 & 14 & 4 \\
\hline
\end{tabular}


milkvetch, and sicklepod milkvetch were 221,167 , and $135 \%$, respectively, of the grass yield from transect increments 1 through 4 where it was the ony species grown. Thus, in all treatments, association of crested wheatgrass with a legume or fourwing saltbush enhanced the regrowth of the grass. The legume forage also contributed directly and importantly to total regrowth forage. Alfalfa recovered faster after clipping than the milkvetch species when first harvested in August 1978 or in May 1979. None of the legumes were able to recover from July to August 1979 when soil moisture was most limiting.

The regrowth rates observed at Nephi indicated that fourwing saltbush and adapted legume species such as alfalfa can make major contributions to forage yield when included in semiarid crested wheatgrass pastures. These gains were made because of an increase in grass yield as well as because of the shrub and legume forage. Extensive plantings of crested wheatgrass exist as monocultures in the western United States. Modification of these pastures by the interseeding of appropriate shrubs and legumes could increase their productivity and value.

\section{Conclusions}

Interplanting of a shrub (fourwing saltbush) or legumes (cicer milkvetch, sicklepod milkvetch, or alfalfa) into a stand of crested whea tgrass significantly increased the forage yield, protein concentration, and protein yield of the grass. The shrub and legume components markedly increased the amount and quality of the forage in the semiarid pasture. These results were measured in 1 year with above-average precipitation and in another with severe drought stress. Total vegetative regrowth was more rapid where fourwing saltbush or legumes grew in association with crested wheatgrass than where only crested wheatgrass was seeded.

\section{Literature Cited}

Bennett, W.H., D.W. Pittman, D.C. Tingey, D.R. McAllister, H.B. Peterson, and I.G. Sampson. 1954. Fifty years of dryland research at the Nephi Field Station. Utah Agr. Exp. Sta. Bull. 371.

Blaisdell, J.P. 1972. Needs and opportunities for shrub research in the western United States. p. 409-413. In: McKell, C.M., J.P. Blaisdell, and J.R. Goodin, eds. Wildland Shrubs-Their Biology and Utilization. Intermountain Forest and Range Exp. Sta. Ogden, Utah.

Charley, J.L. 1977. Mineral cycling in rangeland ecosystems. p. 216-256. In: R.E. Sosebee (ed.), Rangeland plant physiology. Soc. for Range Manage. Range Sci. Ser. No. 4.
Charley, J.L., and N.E. West. 1975. Plant-induced soil chemical patterns in some desert shrub-dominated semi-desert ecosystems of Utah. J. Ecol. 63:945-964.

Chatterton, N.J., and J.E. Silvius. 1979. Photosynthate partitioning into starch in soybean leaves. I. Effects of photoperiod versus photosynthetic period duration. Plant Physiol. 64:749-753.

Cornelius, D.R., and M.W. Talbot. 1955. Rangeland improvement through seeding and weed control of east slope Sierra Nevada and on southern Cascade Mountains. USDA Agr. Handbook No. 88. p. 1-51.

Dubbs, A.L. 1966. Yield, crude protein, and palatability of dryland grasses in central Montana. Montana Agr. Exp. Sta. Bull. 604. p. 1-18.

Fairchild, J.A., and J.D. Brotherson. 1980. Microhabitat relationships of six major shrubs in Navajo National Monument, Arizona. J. Range Manage. 33:150-156.

Frischknecht, N.C. 1963. Contrasting effects of big sagebrush and rubber rabbitbrush on production of crested wheatgrass. J. Range Manage. 16:70-74.

Garcia-Moya, E., and C.M. McKell. 1970. Contribution of shrubs to the nitrogen economy of a desert-wash plant community. Ecology 51:81-88.

Hafenrichter, A.L., J.L. Schwendiman, H.L. Harris, R.S. MacLauchlan, and H.W. Miller. 1968. Grasses and legumes for soil conservation in the Pacific Northwest and Great Basin States. USDA Agr. Handbook No. 339 p. 1-69.

Lorenz, R.J., and G.A. Rogler 1962. A comparison of methods of renovating old stands of crested wheatgrass. J. Range Manage. 15:215-219.

Monsen, S.B. 1980. Interseeding fourwing saltbush (Atriplex canescens Pursh Nutt.) with crested wheatgrass (Agropyron desertorum Schult.) on southern Idaho rangelands. Abstract. Soc. for Range Manage., 33rd Annual Meeting. San Diego, Calif. p. 51.

Nemati, N. 1977. Comparative palatability of Atriplex canescens. J. Range Manage. 30:368-369.

Plummer, A.P., D.R. Christensen, and S.B. Monsen. 1968. Restoring big-game range in Utah. Utah Division of Fish and Game. Pub. No. 68-3. p. $1-183$.

Rittenhouse, L.R., and F.A. Sneva. 1976. Expressing the competitive relationship between $W$ yoming big sagebrush and crested wheatgrass. $J$. Range Manage. 29:326-327.

Rogler, G.A., and R.L. Lorenz. 1969. Pasture productivity of crested wheatgrass as influenced by nitrogen fertilization and alfalfa. USDAARS Tech. Bull. No. 1402 p. 1-33.

Springlield, H.W. 1966. Germination of fourwing saltbush seeds at different levels of moisture stress. Agron. J. 58:149-150.

Townsend, C.E., G.O. Hinze, W.D. Ackermann, and E.E. Remmenga. 1975. Evaluation of forage legumes for rangelands of the Central Plains. Colorado Agr. Exp. Sta. General Ser. 942.

Williams, M.C., L.F. James, and A.T. Bleak. 1976. Toxicity of introduced nitro-containing Astragalus to sheep, cattle, and chicks. J. Range Manage. 29:30-33. 